\title{
Transport, Nutritional and Metabolic Studies of Taurine in Staphylococci
}

\author{
By THEODORE J. GIEHL, $†$ M. WALID QORONFLEH $\ddagger$ AND \\ BR I A N J. WILK I NSON* \\ Microbiology Group, Department of Biological Sciences, Illinois State University, Normal, \\ Illinois 61761, USA
}

(Received 26 June 1986; revised 21 November 1986)

\begin{abstract}
A specific, $\mathrm{Na}^{+}$-dependent, energy-requiring transport system for taurine has been reported recently in the Staphylococcus aureus $\mathrm{M}$ strain. Taurine was taken up vigorously by all $S$. aureus strains tested. The system was $\mathrm{Na}^{+}$-dependent, and $\mathrm{Na}^{+}$decreased the $K_{\mathrm{m}}$ but had no effect on the $V_{\max }$ of the transport system. Among coagulase-negative staphylococci, the Staphylococcus epidermidis group (a taxonomically related group of species associated with humans or other primates) and the free-living, wide-ranging species Staphylococcus sciuri showed vigorous taurine uptake. Somewhat lower rates were found in the Staphylococcus saprophyticus group. Low or barely detectable uptake rates were noted in other staphylococcal species that were primarily of animal origin. No taurine uptake was detected in a variety of other bacterial species tested. Taurine uptake, which was not $\mathrm{Na}^{+}$-dependent, occurred in a Pseudomonas aeruginosa strain grown on taurine as sole energy, carbon, nitrogen, and sulphur source, but not when it was grown in a gluconate/salts medium. In nutritional studies we were unable to demonstrate a role for taurine as a sulphur source for $S$. aureus. $\left[1,2-{ }^{14} \mathrm{C}\right]$ - and $\left[{ }^{35} \mathrm{~S}\right]$ taurine were taken up during overnight growth of cells, and radioactivity was distributed similarly among cellular fractions, indicating that the carbon and sulphur atoms of taurine were not cleaved and had the same fate. We were unable to demonstrate any catabolism of taurine in radiorespirometric experiments to detect evolution of ${ }^{14} \mathrm{CO}_{2}$ by cells incubated with $\left[1,2-{ }^{14} \mathrm{C}\right]$ taurine. Thus, we found no evidence for a role of taurine in the energy, carbon and sulphur metabolism of $S$. aureus.
\end{abstract}

\section{INTRODUCTION}

The occurrence of the sulphonated $\beta$-amino acid taurine was first described in staphylococci as a component of the capsular polysaccharide of the encapsulated Staphylococcus aureus $\mathbf{M}$ strain (Liau et al., 1974). Later, it was shown that a variety of Staph. aureus strains took up radiolabelled taurine from the growth medium during overnight growth, and appeared to carry out some limited metabolism of taurine (Smiley \& Wilkinson, 1983). This led to the discovery of an $\mathrm{Na}^{+}$-dependent, energy-requiring, highly specific uptake system for taurine in the $\mathrm{M}$ strain (Bieber \& Wilkinson, 1984). This previous work prompted a number of questions about the role of taurine in staphylococci. How widespread is the uptake system in staphylococci and other bacteria? What is the role, if any, of the taurine that is taken up in the nutrition of staphylococci? What are the fates of the sulphur and carbon atoms of taurine? In this report we present some of our attempts to answer these questions.

\section{METHODS}

Strains used. The sources of the bacteria studied are shown in Table 2 and below. 'Micrococcus lysodeikticus', Bacillus megaterium KM and Paracoccus denitrificans ATCC 13543 were from the culture collection of this

† Present address: Infectious Diseases Section, VA Medical Center, 1055 Clermont Street, Denver, CO 80220 , USA.

$\ddagger$ Present address: Department of Microbjology and Immunology, University of Louisville Medical School, Louisville, KY 40292, USA. 


\section{Table 1. Components of defined media for growth of staphylococci}

The media, designed to study the role of taurine in sulphur nutrition, were assembled from various combinations of the stock solutions.

\begin{tabular}{|c|c|c|c|}
\hline Stock solution & $\begin{array}{l}\text { Final concn } \\
\text { in medium } \\
\left(\mathrm{mg} \mathrm{l}^{-1}\right)\end{array}$ & Stock solution & $\begin{array}{l}\text { Final concn } \\
\text { in medium } \\
\left(\mathrm{mg} \mathrm{l}^{-1}\right)\end{array}$ \\
\hline Major carbon source & & L-Cystine & 20 \\
\hline $\begin{array}{l}\text { Glucose } \\
\text { or }\end{array}$ & 5000 & $\begin{array}{l}\text { L-Methionine } \\
\text { Taurine }\end{array}$ & $\begin{array}{r}3 \\
950\end{array}$ \\
\hline Glutamate & 4090 & Amino acids & \\
\hline Salts $A$ & & L-Ala & 60 \\
\hline $\mathrm{K}_{2} \mathrm{HPO}_{4}$ & 7000 & L-Arg & 50 \\
\hline $\mathrm{NaH}_{2} \mathrm{PO}_{4} \cdot 2 \mathrm{H}_{2} \mathrm{O}$ & 2300 & L-Asp & 90 \\
\hline$\left(\mathrm{NH}_{4}\right)_{2} \mathrm{SO}_{4}$ & 1000 & L-Glu & 100 \\
\hline $\mathrm{MgCl}_{2}$ & 50 & Gly & 50 \\
\hline Salts $A^{1}$ & & $\mathrm{~L}-\mathrm{His}$ & 20 \\
\hline $\mathrm{K}_{2} \mathrm{HPO}_{4}$ & 7000 & L-Ile & 30 \\
\hline $\mathrm{NaH}_{2} \mathrm{PO}_{4} \cdot 2 \mathrm{H}_{2} \mathrm{O}$ & 2300 & L-Leu & 90 \\
\hline $\mathrm{NH}_{4} \mathrm{Cl}$ & 800 & L-Lys & 50 \\
\hline $\mathrm{MgCl}_{2}$ & 50 & L-Phe & 40 \\
\hline Salts B & & L-Pro & 80 \\
\hline $\mathrm{FeCl}_{3}$ & 128 & L-Ser & 30 \\
\hline Citric acid $\mathrm{H}_{2} \mathrm{O}$ & 210 & L-Thr & 30 \\
\hline Vitamins $A$ & & L-Trp & 10 \\
\hline Thiamin & 1 & L-Tyr & 40 \\
\hline Niacin & $1 \cdot 2$ & L-Val & 80 \\
\hline Vitamins $B$ & & & \\
\hline Calcium pantothenate & 0.25 & & \\
\hline Biotin & 0.005 & & \\
\hline
\end{tabular}

laboratory. Endocarditis isolates of Streptococcus faecalis, 'Streptococcus viridans', Streptococcus bovis, Streptococcus mutans and Serratia marcescens were supplied by W. R. Wilson. Strep. faecalis ATCC 9790 was supplied by F. Harold, Escherichia coli K12 W3110 by D. P. Brunner and Pseudomonas aeruginosa TAU-5 by R. S. Berk. All strains were maintained on Tryptic Soy Agar slants (Difco) at $4{ }^{\circ} \mathrm{C}$.

Transport studies. Staphylococcal strains, 'M. lysodeikticus', B. megaterium and Serr. marcescens were grown in PYK medium (100 ml per $250 \mathrm{ml}$ Erlenmeyer flask), consisting of Phytone peptone (BBL), $5 \mathrm{~g}^{-1} ;$ glucose $2 \mathrm{~g} \mathrm{l}^{-1}$; Bacto Yeast extract (Difco), $5 \mathrm{~g} \mathrm{l}^{-1}$; and $\mathrm{K}_{2} \mathrm{HPO}_{4}, 3 \mathrm{gl}^{-1}$; the $\mathrm{pH}$ was adjusted to $7 \cdot 2-7 \cdot 4$ (Bieber \& Wilkinson, 1984). The inoculum was $1 \mathrm{ml}$ of an overnight culture and cultures were usually grown at $37{ }^{\circ} \mathrm{C}$ with shaking at 200 r.p.m. for about $4 \mathrm{~h}$ to an $\mathrm{OD}_{580}$ of 0.5-1.0 (exponential phase) (Bieber \& Wilkinson, 1984). Two Staph. aureus strains were also grown in a defined medium somewhat modified from that described by Pattee \& Neveln (1975) (Table 1). Glucose or glutamate was used as the major carbon source and the medium was sterilized by filtration. Streptococcal strains were grown in PYK medium containing $2 \%(w / v)$ glucose autoclaved separately. Cultures were inoculated with a loopful of bacteria from a fresh slant and were incubated stationary for 6-8 $\mathrm{h}$ to an $\mathrm{OD}_{580}$ of 0.5-1.0. Pa. denitrificans was grown in succinate/salts medium (Chang \& Morris, 1962). E. coli was grown in medium containing E salts (Vogel \& Bonner, 1956), with $0.5 \%(w / v)$ glucose or glycerol as carbon source (Witholt et al., 1976). Ps. aeruginosa TAU-5 was grown either with taurine as sole energy, carbon, nitrogen and sulphur source in the medium of Shimamoto \& Berk (1979), or in a gluconate/salts medium. When an organism was found not to take up taurine, or take it up poorly, it was retested after growth in medium supplemented with $10 \mathrm{~mm}-\mathrm{NaCl}$ and $1 \mathrm{~mm}$-taurine in an attempt to induce the uptake system. Transport of taurine by bacterial suspensions in buffered glucose in the presence and absence of $10 \mathrm{mM}-\mathrm{NaCl}$ was measured by membrane filtration at intervals as described by Bieber \& Wilkinson (1984). An OD $_{580}$ versus dry weight curve prepared for the Staph. aureus $\mathrm{M}$ strain was used to estimate bacterial dry weight. An $O_{580}$ of 1.0 was equivalent to $0.45 \mathrm{mg} \mathrm{dry} \mathrm{wt} \mathrm{ml}^{-1}$.

Nutritional studies. A loopful of bacteria from a slant was used to inoculate $10 \mathrm{ml}$ defined medium in $50 \mathrm{ml}$ Erlenmeyer flasks which were then incubated with shaking ( 200 r.p.m.) at $37^{\circ} \mathrm{C}$ for $18 \mathrm{~h}$. Samples of $5 \mathrm{ml}$ were collected aseptically by centrifugation at $10000 \mathrm{~g}$ for $15 \mathrm{~min}$ at $4^{\circ} \mathrm{C}$. The cells were washed by resuspension and centrifugation in sterile, cold distilled water. The washed cells were resuspended in $5 \mathrm{ml}$ sterile water and $0.1 \mathrm{ml}$ was used to inoculate $10 \mathrm{ml}$ amounts of the various test media. Growth was measured by determining the $\mathrm{OD}_{580}$ of $1: 10$ diluted samples in a Spectronic 20 spectrophotometer (Bausch \& Lomb).

Uptake and distribution of $\left[{ }^{14} \mathrm{C}\right]$ - and $\left[{ }^{35} \mathrm{~S}\right]$ taurine in overnight grown cells. $\left[1,2-{ }^{14} \mathrm{C}\right] \mathrm{T}$ aurine (specific activity $56.08 \mathrm{mCi} \mathrm{mmol}^{-1} ; 2.08 \mathrm{GBq} \mathrm{mmol}^{-1}$; New England Nuclear) and $\left[{ }^{35}\right.$ S taurine $\left(88.1 \mathrm{mCi} \mathrm{mmol}^{-1}\right.$; 
3.2 GBq mmol-1 ; Amersham) were used in these studies. Cells were grown in PYK medium minus glucose (Smiley \& Wilkinson, 1983) and defined medium ( $25 \mathrm{ml}$ per $50 \mathrm{ml}$ Erlenmeyer flask). Unlabelled taurine was supplied at $0.1 \mathrm{mM}$ and $1 \mu \mathrm{Ci}$ radiolabelled taurine was added. Uptake and distribution of radioactivity among cellular fractions were determined as described by Smiley \& Wilkinson (1983).

Respirometry. Cells were grown to mid-exponential phase in PYK minus glucose medium and were washed in distilled water. Oxygen uptake was studied in $20 \mathrm{ml}$ flasks using a Gilson differential respirometer (Gilson

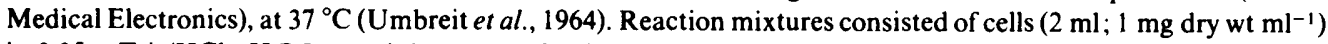
in $0.05 \mathrm{M}$-Tris $/ \mathrm{HCl} \mathrm{pH} 7.5$ containing $10 \mathrm{~mm}-\mathrm{NaCl}$. Experimental additions were 1 or $10 \mathrm{~mm}$-taurine or $30 \mathrm{~mm}^{-}$ glucose.

Radiorespirometry. These studies were done in a similar manner to the respirometric studies. Washed cells were grown in PYK minus glucose medium and the incubations were carried out in sealed $20 \mathrm{ml}$ Gilson respirometer flasks at $37^{\circ} \mathrm{C}$ for $4 \mathrm{~h}$. One $\mu \mathrm{Ci}$ of $\left[1,2^{-14} \mathrm{C}\right]$ taurine or $\mathrm{D}-\left[\mathrm{U}^{-14} \mathrm{C}\right] \mathrm{glucose}\left(3.9 \mathrm{mCi} \mathrm{mmol}{ }^{-1} ; 0.14 \mathrm{GBq} \mathrm{mmol}^{-1}\right.$; New England Nuclear) was included with the washed cells $(2 \mathrm{ml})$ in $0.05 \mathrm{M}-\mathrm{Tris} / \mathrm{HCl} \mathrm{pH} 7.5$ containing $10 \mathrm{~mm}-\mathrm{NaCl}$ and unlabelled taurine ( $0.1 \mathrm{mM}$ ) or D-glucose $(0.1 \mathrm{mM})$. Hyamine hydroxide (1 M-methylbenzethonium hydroxide in methanol, Sigma) $(0.2 \mathrm{ml})$ was placed in the centre well to absorb any evolved ${ }^{14} \mathrm{CO}_{2}$, which was detected by liquid scintillation counting. Samples were kept in the dark before counting. This method resembles that described by Hackstadt \& Williams (1981).

\section{RESULTS}

\section{Additional characteristics of taurine transport in the Staph. aureus $M$ strain}

Previous studies characterized the taurine transport system in the $M$ strain (Bieber \& Wilkinson, 1984). Before investigating the occurrence of the taurine transport system in other bacteria, we examined some additional characteristics of the system in the $M$ strain. Uptake was more rapid by cells harvested from the exponential phase than from the stationary phase of growth (Table 2). Initial uptake rates were similar in cells grown in PYK, PYK minus glucose and defined media (Table 2). A variety of $\mathrm{Na}^{+}$salts were comparably efficient to $\mathrm{NaCl}$ in supplying the $\mathrm{Na}^{+}$requirement of the system, including phosphate, nitrate, sulphate, citrate and acetate salts (data not shown). This indicates that the anion is unimportant in taurine uptake.

Our previous studies of the kinetic parameters of taurine uptake in the $\mathbf{M}$ strain revealed a

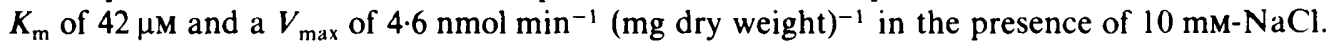
Decreasing concentrations of $\mathrm{NaCl}$ increased the $K_{\mathrm{m}}$ of the system and appeared to decrease the $V_{\text {max }}$. Study of the kinetic parameters of taurine uptake in the presence of $10 \mathrm{~mm}-\mathrm{NaCl}$ by Staph. aureus strains Lafferty, Endo and Oughterson revealed $K_{\mathrm{tn}}$ values of $38.5,40.0$ and $41.6 \mu \mathrm{M}$, and $V_{\max }$ values of $7 \cdot 2,8.9$ and $6.2 \mathrm{nmol} \mathrm{min}{ }^{-1}\left(\mathrm{mg}\right.$ dry weight) ${ }^{-1}$, respectively. Decreasing the $\mathrm{NaCl}$ concentration increased the $K_{\mathrm{m}}$ values but had essentially no effect on the $V_{\max }$ values (data not shown).

\section{Survey of taurine transport}

The results of the survey for the taurine transport system are shown in Table 2. Unless stated otherwise, strains were grown in PYK medium to the exponential phase of growth. Results are expressed as the initial rate of uptake in the presence and absence of $\mathrm{Na}^{+}$and the uptake attained after $15 \mathrm{~min}$ (Bieber \& Wilkinson, 1984). In all staphylococcal strains there was much more taurine uptake in the presence of $\mathrm{Na}^{+}$than in its absence. All 20 Staph. aureus strains tested took up taurine vigorously. The mean initial uptake rate in the presence of $\mathrm{Na}^{+}$was $1 \cdot 27$

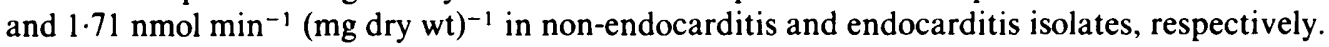
The uptake of taurine by coagulase-negative species was slower than that by Staph.aureus. Of six Staph. epidermidis endocarditis isolates tested, three had relatively high uptake rates and three relatively low rates. Vigorous uptake was noted by Staph. simulans, Staph. capitis, Staph. haemolyticus, Staph. hominis, Staph. warneri and Staph. sciuri. Somewhat lower initial rates of uptake were noted in a group comprised of Staph. saprophyticus, Staph. cohnii and Staph. xylosus. Low, or very low, taurine uptake activity was detected in Staph. hyicus, Staph. lentus, Staph. auricularis, Staph. hyicus subsp. chromogenes and Staph. intermedius. Thus, the possession of an $\mathrm{Na}^{+}$-dependent taurine uptake system was a general property of several staphylococcal strains, although some coagulase-negative species showed very low activities. 


\section{Table 2. Taurine transport among various species of Staphylococcus}

Uptake was measured in exponential-phase cells grown in PYK medium unless stated otherwise. The initial rate of uptake and the uptake attained after $15 \mathrm{~min}$ are shown. The values represent the results of one experiment.

$\quad \begin{aligned} & \text { Organism } \\ & \text { (medium and growth phase) }\end{aligned}$
S. aureus M (PYK, exponential)
S. aureus M (PYK, stationary)
S. aureus M (PYK minus glucose,
exponential)
S. aureus M (defined,
exponential)
S. aureus Lafferty
S. aureus Smith diffuse
S. aureus SA222
S. aureus Oxford
S. aureus Wood 46
S. aureus NS58D
S. aureus Cowan I
S. aureus Copenhagen
S. aureus $\mathrm{M}$ variant

S. aureus DU4916

$S$. aureus $\mathrm{H}$

S. aureus ATCC 6538P

S. aureus Mastitis

S. aureus Pelezinski

$S$. aureus ENDO

$S$. aureus Kurch

S. aureus Mah

$S$. aureus Pope

$S$. aureus Stoiber

$S$. epidermidis II-5

S. epidermidis ATCC 14990

$S$. epidermidis Burk

$S$. epidermidis Grooms

$S$. epidermidis Gregg

$S$. epidermidis Oster

$S$. epidermidis Oughterson

$S$. epidermidis Rambo

S. xylosus TPC 1

S. xylosus SE 4

S. simulans ML 26

S. simulans ATCC 27848

S. capitis $\mathrm{LH} \mathrm{A} 3$

S. capitis ATCC 27840

$S$. haemolyticus KH 11

S. haemolyticus DSM 20263

$S$. hominis ATCC 27844

S. hominis DGS 73

S. cohnii BB 3

S. cohnii DSM 20260

S. saprophyticus ATCC 15305

S. saprophyticus GH 196

S. sciuri 29059

S. sciuri GV 234

$S$. lentus FB 2

S. lentus $\mathrm{K} 6$

$S$. warneri KL 105

$S$. intermedius CF 238

S. auricularis ATCC 33757

S. hyicus NCTC 10350

$S$. hyicus subsp. chromogenes LSU 89LR
Source and comments

This lab., encapsulated

L. J. Wheat

This lab., encapsulated

This lab., encapsulated

This lab.

This lab.

This lab., encapsulated

This lab.

D. J. Tipper

This lab., unencapsulated derivative of $\mathbf{M}$ strain

This lab., methicillin-resistant

This lab.

S. Silver

This lab., bovine mastitis isolate

T. E. West, endocarditis isolate

R. Procter, endocarditis isolate

T. E. West, endocarditis isolate

T. E. West, endocarditis isolate

T. E. West, endocarditis isolate

T. E. West, endocarditis isolate

This lab., methicillin-resistant

This lab.

T. E. West, endocarditis isolate

T. E. West, endocarditis isolate

T. E. West, endocarditis isolate

T. E. West, endocarditis isolate

T. E. West, endocarditis isolate

T. E. West, endocarditis isolate

This lab.

W. E. Kloos

This lab.

W. E. Kloos

This lab.

W. E. Kloos

W. E. Kloos

W. E. Kloos

W. E. Kloos

W. E. Kloos

W. E. Kloos

W. E. Kloos

This lab.

W. E. Kloos

W. E. Kloos

W. E. Kloos

This lab.

W. E. Kloos

W. E. Kloos

W. E. Kloos

W. E. Kloos

W. E. Kloos

W. E. Kloos
Taurine uptake [nmol (mg dry $w)^{-1}$ ]

\begin{tabular}{llll}
$\overbrace{+\mathrm{Na}^{+}}^{2}$ & $-\mathrm{Na}^{+}$ & & \multicolumn{3}{c}{ After $1 \mathrm{~min}$} & $\overbrace{+\mathrm{Na}^{+}}$ & $-\mathrm{Na}^{+}$ \\
1.20 & 0.11 & 3.80 & 1.50 \\
0.60 & 0.03 & 1.70 & 0.20 \\
& & & \\
1.21 & 0.16 & 3.66 & 1.54 \\
& & & \\
1.36 & 0.19 & 4.30 & 1.36 \\
1.50 & 0.11 & 3.80 & 1.50 \\
2.27 & 0.21 & 4.40 & 1.40 \\
1.02 & 0.19 & 4.03 & 1.29 \\
1.99 & 0.20 & 3.51 & 1.40 \\
0.80 & 0.06 & 3.30 & 0.49 \\
1.40 & 0.25 & 3.20 & 1.40 \\
0.70 & 0.02 & 3.10 & 0.62 \\
0.90 & 0.03 & 3.00 & 0.32
\end{tabular}

$\begin{array}{llll}1.22 & 0.07 & 2.60 & 0.96\end{array}$

$\begin{array}{llll}0.70 & 0.01 & 2.23 & 0.17\end{array}$

$\begin{array}{llll}1.42 & 0.39 & 2.16 & 1.40\end{array}$

$\begin{array}{llll}0.76 & 0.02 & 3.10 & 0.06\end{array}$

$\begin{array}{llll}1.96 & 0.05 & 3.62 & 0.21\end{array}$

$\begin{array}{llll}2.20 & 0.21 & 3.40 & 1.35\end{array}$

$\begin{array}{llll}1.62 & 0.19 & 3.33 & 110\end{array}$

$\begin{array}{llll}1.53 & 0.16 & 3.23 & 1.00\end{array}$

$\begin{array}{llll}1.60 & 0.19 & 3.10 & 1.00\end{array}$

$\begin{array}{llll}1.60 & 0.12 & 3.10 & 0.79\end{array}$

$\begin{array}{llll}1.70 & 0.20 & 3.00 & 1.20\end{array}$

$\begin{array}{llll}0.70 & 0.03 & 3.30 & 0.40\end{array}$

$\begin{array}{llll}0.41 & 0.01 & 2.51 & 0.21\end{array}$

$\begin{array}{llll}0.27 & 0.00 & 4.39 & 0.05\end{array}$

$\begin{array}{llll}0.44 & 0.00 & 3.30 & 0.07\end{array}$

$\begin{array}{llll}0.83 & 0.02 & 2.87 & 0.07\end{array}$

$\begin{array}{llll}1.00 & 0.01 & 3.30 & 0.05\end{array}$

$\begin{array}{llll}1.13 & 0.01 & 4.14 & 0.12\end{array}$

$\begin{array}{llll}0.35 & 0.00 & 3.76 & 0.04\end{array}$

$\begin{array}{llll}0.30 & 0.04 & 2.00 & 0.84\end{array}$

$\begin{array}{llll}0.30 & 0.05 & 2.13 & 0.61\end{array}$

$\begin{array}{llll}0.81 & 0.02 & 3.51 & 0.47\end{array}$

$\begin{array}{llll}0.60 & 0.02 & 2.90 & 0.54\end{array}$

$\begin{array}{llll}0.50 & 0.03 & 2.13 & 0.23\end{array}$

$\begin{array}{llll}0.90 & 0.22 & 3.20 & 1.53\end{array}$

$\begin{array}{llll}0.70 & 0.06 & 3.74 & 1.40\end{array}$

$\begin{array}{llll}0.50 & 0.05 & 2.60 & 1.00\end{array}$

$\begin{array}{llll}0.93 & 0.06 & 3.20 & 1.25\end{array}$

$\begin{array}{llll}0.30 & 0.01 & 2.02 & 0.21\end{array}$

$\begin{array}{llll}0.30 & 0.03 & 2.44 & 0.44\end{array}$

$\begin{array}{llll}0.20 & 0.01 & 1.70 & 0.16\end{array}$

$\begin{array}{llll}0.21 & 0.01 & 1.64 & 0.28\end{array}$

$\begin{array}{llll}0.51 & 0.02 & 2.88 & 0.05\end{array}$

$\begin{array}{llll}0.84 & 0.22 & 3.20 & 1.50\end{array}$

$\begin{array}{llll}0.31 & 0.00 & 1.50 & 0.01\end{array}$

$\begin{array}{llll}0.01 & 0.00 & 0.20 & 0.00\end{array}$

$\begin{array}{llll}0.60 & 0.10 & 3.44 & 1.20\end{array}$

$\begin{array}{llll}1.02 & 0.05 & 4.60 & 0.71\end{array}$

$\begin{array}{llll}0.12 & 0.00 & 0.60 & 0.00\end{array}$

$\begin{array}{llll}0.05 & 0.00 & 0.40 & 0.00\end{array}$

$\begin{array}{llll}0.32 & 0.00 & 1.40 & 0.03\end{array}$

$\begin{array}{llll}0.08 & 0.00 & 0.43 & 0.00\end{array}$ 
Table 3. Influence of taurine on the growth of Staph. aureus with various sulphur sources

Each medium contained either glucose (Glc) or glutamate (Glu) as major carbon source plus salts B, vitamins A, vitamins $B$ and amino acids (see Table 1 ). In addition the various media contained: 1 , salts $A$, cystine, methionine; 2 , salts $A$, cystine, methionine, taurine; 3 , salts $A^{1}$, cystine, methionine; 4 , salts $A^{1}$, cystine, methionine, taurine; 5 , salts $A ; 6$, salts $A$, taurine; 7 , salts $A^{1} ; 8$, salts $A^{1}$, taurine.

\begin{tabular}{|c|c|c|c|c|c|c|c|c|c|c|c|c|c|c|c|c|}
\hline \multirow[b]{2}{*}{ Strain } & \multicolumn{16}{|c|}{ Medium and growth $\left(\mathrm{OD}_{580}\right)$} \\
\hline & $\begin{array}{c}1 \\
\text { Glc }\end{array}$ & $\begin{array}{c}1 \\
\text { Glu }\end{array}$ & $\begin{array}{c}2 \\
\text { Glc }\end{array}$ & $\begin{array}{c}2 \\
\text { Glu }\end{array}$ & $\begin{array}{c}3 \\
\text { Glc }\end{array}$ & $\begin{array}{c}3 \\
\text { Glu }\end{array}$ & $\begin{array}{c}4 \\
\text { Glc }\end{array}$ & $\begin{array}{c}4 \\
\text { Glu }\end{array}$ & $\begin{array}{c}5 \\
\text { Glc }\end{array}$ & $\begin{array}{c}5 \\
\text { Glu }\end{array}$ & $\begin{array}{c}6 \\
\text { Glc }\end{array}$ & $\begin{array}{c}6 \\
\text { Glu }\end{array}$ & $\begin{array}{c}7 \\
\text { Glc }\end{array}$ & $\begin{array}{c}7 \\
\text { Glu }\end{array}$ & $\begin{array}{c}8 \\
\text { Glc }\end{array}$ & $\begin{array}{c}8 \\
\text { Glu }\end{array}$ \\
\hline $\begin{array}{l}\text { M } \\
\text { ENDO }\end{array}$ & $\begin{array}{l}3.7 \\
4.8\end{array}$ & $\begin{array}{l}2 \cdot 9 \\
3 \cdot 4\end{array}$ & $\begin{array}{l}2 \cdot 9 \\
4 \cdot 1\end{array}$ & $\begin{array}{l}2.2 \\
3.6\end{array}$ & $\begin{array}{l}3 \cdot 6 \\
4 \cdot 6\end{array}$ & $\begin{array}{l}2.2 \\
3.6\end{array}$ & $\begin{array}{l}2 \cdot 6 \\
4 \cdot 2\end{array}$ & $\begin{array}{l}2 \cdot 2 \\
3 \cdot 6\end{array}$ & $\begin{array}{l}0 \cdot 10 \\
0\end{array}$ & $\begin{array}{l}0 \\
0\end{array}$ & $\begin{array}{l}0.07 \\
0\end{array}$ & $\begin{array}{l}0 \\
0\end{array}$ & $\begin{array}{l}0.05 \\
0\end{array}$ & $\begin{array}{l}0 \\
0\end{array}$ & $\begin{array}{l}0 \cdot 05 \\
0\end{array}$ & $\begin{array}{l}0 \\
0\end{array}$ \\
\hline
\end{tabular}

We were unable to detect taurine uptake in Strep. faecalis, 'Strep. viridans', Strep. bovis, Strep. mutans, Serr. marcescens, B. megaterium, Pa. denitrificans, 'M. lysodeikticus' or $E$. coli, whether or not the strains had been grown in the presence of taurine, which indicated that the system was not inducible. Several of the strains tested were endocarditis isolates.

Ps. aeruginosa TAU-5 took up taurine when the cells were grown in a medium where taurine served as $\mathrm{C}, \mathrm{N}, \mathrm{S}$ and energy source. However, the system was not dependent on $\mathrm{Na}^{+}$, and the absence of glucose from the assay mixture did not diminish uptake, in contrast to the finding with Staph. aureus (Bieber \& Wilkinson, 1984). Shaking increased uptake by $25 \%$. Negligible uptake occurred at $0{ }^{\circ} \mathrm{C}$, indicating that we were not observing simple binding of taurine to cells. However, no uptake occurred when the strain was grown in gluconate/salts medium, which indicates that the taurine uptake system was inducible.

\section{Nutritional studies of taurine in Staph. aureus}

The defined medium used was modified from that described by Pattee $\&$ Neveln (1975). We attempted to observe any stimulatory effect taurine might have on growth, and focussed on whether taurine could serve as a sulphur source for staphylococci (Smiley \& Wilkinson, 1983). In most experiments glucose served as the major carbon source and sulphur was supplied in the form of $\left(\mathrm{NH}_{4}\right)_{2} \mathrm{SO}_{4}$, cystine and methionine, and in minor amounts in the form of the vitamins thiamin and biotin. Staph. aureus strains M and ENDO were used in these experiments.

Both strains grew well in complete defined medium. Omission of methionine decreased the $\mathrm{OD}_{580}$ achieved in overnight growth and omission of cystine resulted in even less growth. Omission of both amino acids simultaneously led to poor growth and supplementation with taurine did not lead to increased growth. This indicates that Staph. aureus is auxotrophic for cystine in particular. Similar results were obtained when glutamate served as the major carbon source.

With regard to major sulphur sources the following combinations were investigated (Table 3): 1, $\left(\mathrm{NH}_{4}\right)_{2} \mathrm{SO}_{4}$, cystine, methionine; $2,\left(\mathrm{NH}_{4}\right)_{2} \mathrm{SO}_{4}$, cystine, methionine, taurine; 3 , cystine, methionine; 4 , cystine, methionine, taurine; $5,\left(\mathrm{NH}_{4}\right)_{2} \mathrm{SO}_{4} ; 6,\left(\mathrm{NH}_{4}\right)_{2} \mathrm{SO}_{4}$, taurine; 7 , none; 8 , taurine. Taurine did not stimulate growth when $\left(\mathrm{NH}_{4}\right)_{2} \mathrm{SO}_{4}+$ cystine + methionine and cystine + methionine served as major sulphur sources. In fact growth was somewhat less when taurine was present. When $\left(\mathrm{NH}_{4}\right)_{2} \mathrm{SO}_{4}$ or taurine alone was the sulphur source, negligible or no growth occurred, even on prolonged $(42 \mathrm{~h})$ incubation. Similar results were obtained with glutamate as major carbon source (Table 3 ). Thus we were unable to provide any evidence that taurine was able to serve as a source of sulphur for staphylococci.

\section{Respirometric and radiorespirometric studies with taurine}

The data of Smiley \& Wilkinson (1983) had shown a discrepancy between uptake of taurine measured by disappearance from growth medium, and as cell-associated radioactivity. It seemed possible that catabolism of taurine to $\mathrm{CO}_{2}$ could account for the missing radioactivity. Taurine did not stimulate the oxygen consumption of Staph. aureus strain NS58D above the endogenous rate. In previous studies this strain had shown the largest discrepancy in taurine uptake measured by disappearance versus cell-associated radioactivity (Smiley $\&$ Wilkinson, 
Table 4. Radiorespirometric studies of taurine and glucose metabolism by three Staph. aureus strains

The values are the results of a representative experiment.

\begin{tabular}{|c|c|c|c|}
\hline \multirow[b]{2}{*}{ Conditions } & \multicolumn{3}{|c|}{$\begin{array}{l}\text { Radioactivity (c.p.m.) } \\
\text { in hyamine hydroxide }\end{array}$} \\
\hline & $\mathbf{M}$ & ENDO & NS58D \\
\hline $\mathrm{e}+\mathrm{l} u \mathrm{Ci}\left[\mathrm{U}^{-14} \mathrm{Clg}\right]_{2}$ & $\begin{array}{r}442 \\
2667\end{array}$ & $\begin{array}{r}273 \\
2941\end{array}$ & $\begin{array}{r}715 \\
3344\end{array}$ \\
\hline & 1090 & 1406 & 2622 \\
\hline
\end{tabular}

Table 5. Uptake and distribution of radioactivity from $[1,2-14 \mathrm{C}]$ - and $\left[{ }^{35} S\right]$ taurine among cellular fractions by three Staph. aureus strains grown overnight in complex and defined media

The values are the means of two separate experiments.

Cells alone

No cells, $1 \mu \mathrm{Ci}\left[1,2-1^{14} \mathrm{C}\right]$ taurine $+1 \mu \mathrm{Ci}\left[\mathrm{U}^{-14} \mathrm{C}\right] \mathrm{glucose}$

Cells $+1 \mu \mathrm{Ci}\left[1,2^{-14} \mathrm{C}\right]$ taurine

Cells $+1 \mu \mathrm{Ci}\left[\mathrm{U}-{ }^{14} \mathrm{C}\right] \mathrm{glucose}$
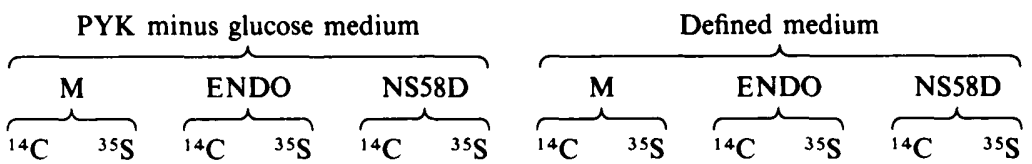

Fraction

Spent medium

Harvested cells

Pool metabolites

Lipid

Nucleic acid-teichoic

acid-capsular

polysaccharide

Protein

Peptidoglycan

\begin{tabular}{lllllll} 
& \multicolumn{4}{c}{ Percentage uptake* $^{*}$}
\end{tabular}

$23 \quad 36 \quad 33$

$\begin{array}{rrr}94 & 94 & 97 \\ 4.7 & 3 & 3\end{array}$

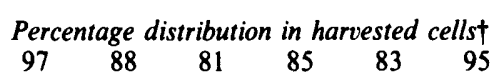

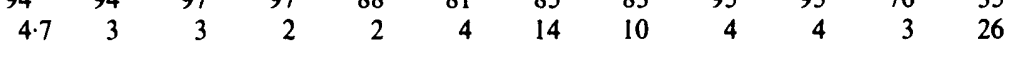

$\begin{array}{rrrrrrrrrrrr}<1 & 3 & <1 & <1 & 8 & 12 & <1 & 5 & <1 & <1 & 14 & 36 \\ <1 & <1 & <1 & <1 & <1 & <1 & <1 & <1 & <1 & <1 & <1 & <1 \\ <1 & <1 & <1 & <1 & 2 & 2 & <1 & 2 & <1 & <1 & 7 & 2\end{array}$

* Percentage of total radioactivity supplied taken up by cells calculated by difference between uninoculated and spent medium or by direct counting of cells (Smiley \& Wilkinson, 1983).

$\dagger$ The starting radioactivity in harvested cells $(100 \%)$ was $10^{5}-10^{6}$ c.p.m.

1983). Substantial oxygen uptake was observed when glucose was supplied as a substrate (data not shown). Because of these negative results we tested for the evolution of ${ }^{14} \mathrm{CO}_{2}$ from [1,2${ }^{14} \mathrm{C}$ ]taurine as a more sensitive assay for the catabolism of taurine.

No release of ${ }^{14} \mathrm{CO}_{2}$ was detected upon incubation of washed cell suspensions of Staph. aureus strains $\mathrm{M}$, ENDO and NS58D with $\left[1,2-{ }^{14} \mathrm{C}\right]$ taurine, whereas substantial release was noted from $D-\left[U-{ }^{14} \mathrm{C}\right]$ glucose, which was used as a control (Table 4). We conclude that no substantial catabolism of the taurine carbon skeleton occurred under the conditions studied.

Uptake and distribution of $\left[1,2-{ }^{14} \mathrm{C}\right]$ - and $\left[{ }^{35} \mathrm{~S}\right]$ taurine in overnight grown cells

In order to obtain information on the fate of the sulphur atom of taurine taken up by Staph. aureus, the uptake and distribution of radioactivity from $\left[{ }^{35} S\right]$ taurine among fractions in cells grown in PYK minus glucose and defined media were compared with the uptake and distribution of $\left[1,2-{ }^{14} \mathrm{C}\right]$ taurine (Table 5). Substantial amounts of both $\left[1,2-{ }^{14} \mathrm{C}\right]-$ and $\left[{ }^{35}\right.$ S]taurine were taken up by the three strains studied from both PYK minus glucose and defined media. Similar amounts of $\left[1,2-{ }^{14} \mathrm{C}\right]$ - and $\left[{ }^{35} \mathrm{~S}\right]$ taurine were taken up by the strains grown in PYK minus glucose medium (Table 5). Similar percentage uptake values were obtained by measuring uptake by counting either spent medium or harvested cells. The strains appeared to take up somewhat less $\left[{ }^{35} \mathrm{~S}\right]$ taurine than $\left[1,2-{ }^{14} \mathrm{C}\right]$ taurine when grown in defined 
medium. Measuring uptake of $\left[{ }^{35} S\right]$ taurine by counting harvested cells indicated substantially less uptake than by counting spent medium in the case of defined medium. In PYK minus glucose medium radioactivity from $\left[1,2-{ }^{14} \mathrm{C}\right]$ - and $\left[{ }^{35} \mathrm{~S}\right]$ taurine was similarly distributed among the cellular fractions. In this medium most of the radioactivity remained in the pool metabolites fraction in all strains with either isotope. Strain NS58D incorporated radioactivity into other cellular fractions, consistent with previous observations (Smiley \& Wilkinson, 1983). Basically similar results were seen when defined medium was used, i.e. the distribution of radioactivity from $\left[1,2-{ }^{14} \mathrm{C}\right]-$ and $\left[{ }^{35} \mathrm{~S}\right]$ taurine was similar, indicating that the carbon and sulphur atoms of taurine had similar fates. In strain NS58D grown in defined medium, more radioactivity from $\left[1,2-{ }^{14} \mathrm{C}\right]$ taurine appeared to be present in the pool metabolites fraction than from $\left[{ }^{35} \mathrm{~S}\right]$ taurine. Overall, because of the similarity of the distribution of radioactivity from $\left[1,2-{ }^{14} \mathrm{C}\right]$ - and $\left[{ }^{35} S\right]$ taurine, the results indicated that cleavage of the carbon and sulphur atoms of taurine had not occurred.

\section{DISCUSSION}

A taurine transport system of high activity was present in Staphylococcus aureus [mean 1.40, range $0 \cdot 80-2 \cdot 27 \mathrm{nmol} \mathrm{min}^{-1}\left(\mathrm{mg}\right.$ dry wt) ${ }^{-1}$ ]. Relatively high activities were present in $S$. epidermidis, $S$. hominis, $S$. warneri, $S$. simulans, $S$. capitis, $S$. haemolyticus [mean of all strains $0 \cdot 67$, range $0.30-1.02 \mathrm{nmol} \mathrm{min}^{-1}\left(\mathrm{mg}\right.$ dry wt) ${ }^{-1}$ ) and $S$. sciuri [mean 0.58 , range $0.31-0.84 \mathrm{nmol}$ $\mathrm{min}^{-1}(\mathrm{mg} \mathrm{dry} \mathrm{wt})^{-1}$ ]. $S$. epidermidis and the other coagulase-negative species above, except $S$. simulans and $S$. sciuri, compose the $S$. epidermidis species group as defined by phenotypic characteristics and DNA-DNA hybridization studies (Kloos, 1980). Staphylococci of the $S$. saprophyticus species group, composed of $S$. saprophyticus, $S$. xylosus and $S$. cohnii, all showed lower initial uptake rates than the aforementioned species [mean $0 \cdot 30$, range $0 \cdot 20$ $0.51 \mathrm{nmol} \mathrm{min}^{-1}(\mathrm{mg} \text { dry } \mathrm{wt})^{-1}$ ]. The staphylococcal species showing poor uptake were of animal origin, with the exception of $S$. auricularis [mean 0.08 , range $0.01-0.60 \mathrm{nmol} \mathrm{min}{ }^{-1}(\mathrm{mg}$ dry $w t)^{-1}$ ]. $S$. sciuri, like $S$. xylosus, is a free-living, wide-ranging species (Kloos, 1980). In the absence of knowledge of the function of the taurine uptake system it is difficult to appreciate the significance of the different levels of activities in the different groups, which appear to be reflecting the different evolutionary histories of the species. Taurine is present in high concentrations in the tissues of man and other animals, in particular heart tissue (Jacobsen \& Smith, 1968).

A taurine transport system was not detected in a variety of other bacterial species, several of which were endocarditis isolates. Again without knowledge of the function of the system it is difficult to explain its apparent staphylococcal specificity. The taurine uptake system in $P S$. aeruginosa had different properties from the staphylococcal one, notably in its $\mathrm{Na}^{+}-$ independence.

In view of the finding that a taurine transport system is a characteristic of a variety of staphylococcal species it would appear likely that the taurine is taken up for some purpose. However, we have not yet discovered the role of the taurine transport system in staphylococcal physiology. One possibility is that it is not a taurine transport system at all, but exists for the uptake of some other molecule. However, we consider this to be unlikely because the system is highly specific for taurine. None of the common amino acids tested competed with taurine for uptake, and only two compounds closely related to taurine showed any inhibition of taurine uptake (Bieber \& Wilkinson, 1984).

We had previously speculated (Smiley \& Wilkinson, 1983) that if taurine were cleaved to sulphite, as it is in Ps. aeruginosa (Shimamoto \& Berk, 1979), then taurine might be able to feed into a postulated staphylococcal sulphate assimilation pathway by analogy to that in other bacteria. However, we were unable to demonstrate a contribution of taurine to the sulphur requirements of $S$. aureus through our nutritional studies. It is possible, but we consider it unlikely, that the nutritional requirement for cystine is obscuring a contribution of taurine to $S$. aureus sulphur nutrition. Also, studies of the uptake and distribution of $\left[{ }^{14} \mathrm{C}\right]-$ and $\left[{ }^{35} \mathrm{~S}\right]$ taurine, which gave very similar results, showed no evidence for cleavage of the carbon-sulphur bond. 
We have been unable to demonstrate a role for taurine in the carbon and energy metabolism of $S$. aureus. No evolution of ${ }^{14} \mathrm{CO}_{2}$ by cells incubated with $\left[{ }^{14} \mathrm{C}\right]$ taurine could be detected. The discrepancy between taurine uptake measured by counting spent medium and harvested cells noted previously (Smiley \& Wilkinson, 1983) was probably due to different degrees of quenching in the samples. In support of this, a similar discrepancy was noted in measuring the uptake of $\left.{ }^{[35} \mathrm{S}\right]$ taurine in cells grown in defined medium.

It is possible that taurine could provide a source of nitrogen for staphylococci by participating in transamination reactions, similar to those known to occur in other micro-organisms (Shimamoto \& Berk, 1979). Such a role would be difficult to demonstrate given the multiple amino acid auxotrophies of $S$. aureus.

Rather, it appears that taurine is relatively metabolically inert once it has been taken up by staphylococci, although chromatographic evidence indicates that it may undergo a limited transformation (Bieber \& Wilkinson, 1984; Smiley \& Wilkinson, 1983). Metabolic inertness is characteristic of taurine in a wide range of organisms (Jacobsen \& Smith, 1968). A possible role for taurine, or a closely related metabolite, would be as an osmoregulatory molecule. Taurine is known to have an osmoregulatory function in a variety of organisms (Huxtable, 1980; Jacobsen \& Smith, 1968). Staphylococci are halotolerant, and proline is a known osmoregulator in these organisms, as it is in a variety of other bacteria (Koujima et al., 1978; Measures, 1975). Taurine is present in high concentrations in animal tissues and it would appear logical that staphylococci might have evolved the ability to utilize taurine as an osmoregulator. In preliminary experiments increases in the medium $\mathrm{NaCl}$ concentration increased the amount of taurine taken up during overnight growth by the $S$. aureus $M$ strain (T. J. Giehl \& B. J. Wilkinson, unpublished observations). Future experiments will be devoted to examining this possible role for taurine in staphylococci.

We are grateful to the investigators who generously supplied strains, and to Wayne Riddle for help with the respirometry experiments. This work was supported by a Grant-in-Aid from the American Heart AssociationIllinois Affiliate.

\section{REFERENCES}

Bieber, E. J. \& Wilkinson, B. J. (1984). Sodiumdependent uptake of taurine in encapsulated Staphylococcus aureus strain M. Biochimica et biophysica acta 770, 127-135.

Chang, J. P. \& Morris, J. G. (1962). Studies on the utilization of nitrate by Micrococcus denitrificans. Journal of General Microbiology 29, 301-310.

HackstadT, T. \& Williams, J. C. (1981). Biologica! stratagem for obligate parasitism of eukaryotic cells by Coxiella burnetii. Proceedings of the National Academy of Sciences of the United States of America 78, 3240-3244.

HuXtable, R. J. (1980). Does taurine have a function? Federation Proceedings 39, 2678-2679.

JACOBSEN, J. G. \& SMITH, J. L., JR (1968). Biochemistry and physiology of taurine and taurine derivatives. Physiological Reviews 48, 424-509.

KLOOS, W. E. (1980). The genus Staphylococcus. Annual Review of Microbiology 34, 559-592.

Koujima, I., Hayashi, H., Tomochika, K., OKabe, A. \& Kanemasa, Y. (1978). Adaptional change in proline and water content of Staphylococcus aureus after alteration of environmental salt concentration. Applied and Environmental Microbiology 35, 467-470.

Liau, D.-F., Melly, M. A. \& Hash, J. H. (1974). Surface polysaccharide from Staphylococcus aureus $M$ that contains taurine, D-aminogalacturonic acid, and D-fucosamine. Journal of Bacteriology 119, 913922.

Measures, J. C. (1975). Role of amino acids in osmoregulation of non-halophilic bacteria. Nature, London 257, 398-400.

Pattee, P. \& Neveln, D. S. (1975). Transformation analysis of three linkage groups in Staphylococcus aureus. Journal of Bacteriology 124, 201-211.

Shimamoto, G. \& BerK, R. S. (1979). Catabolism of taurine in Pseudomonas aeruginosa. Biochimica et biophysica acta 569, 287-292.

Smiley, D. W. \& Wilkinson, B. J. (1983). Survey of taurine uptake and metabolism in Staphylococcus aureus. Journal of General Microbiology 129, 24212428.

Umbreit, W. W., Burris, R. H. \& Stauffer, J. F. (1964). Manometric Techniques, 4th edn. Burgess, Minneapolis, USA.

VoGel, H. J. \& BONNER, D. M. (1956). Acetylornithinase of Escherichia coli: partial purification and some properties. Journal of Biological Chemistry 218, 97106.

Witholt, B., BOEKhOUT, M., BROCK, M., KINGMA, J., Van Herrikhuizen, H. \& DeleiJ, L. (1976). An efficient and reproducible procedure for the formation of spheroplasts from variously grown Escherichia coli. Analytical Biochemistry 74, 160-170. 